\title{
PACKARD INSTRUMENT COMPANY RADIOCARBON DATES II
}

\author{
SANDRA J. KOWALSKI and ARIEL G. SCHRODT
}

Packard Instrument Company, Inc., Downers Grove, Illinois

The measurements reported in the following date list have been made in the Low Level Counting Laboratory of Packard Instrument Company during 1965 and are a continuation of the work reported previously (Packard I). This counting procedure for these dates has remained unchanged - a $5 \mathrm{ml}$ volume of benzene counted in a Packard Tri-Carb ${ }^{\circledR}$ Liquid Scintillation Spectrometer Model 3214. The sample is converted chemically from its original form to benzene in the Packard Tri-Carb Benzene Synthesizer. This instrument was described in a general fashion in our previous publication.

The chemical reactions involved in the conversion of the sample to benzene are as follows:

1) organic sample $+\mathrm{O}_{2} \rightarrow \mathrm{CO}_{2}+\mathrm{H}_{2} \mathrm{O}$

or

inorganic sample $+\mathrm{HCl} \mathrm{CO} \mathrm{C}_{2}+\mathrm{H}_{2} \mathrm{O}$

2) $2 \mathrm{CO}_{2}+10 \mathrm{Li} \mathrm{Li}_{2} \mathrm{C}_{2}+4 \mathrm{Li}_{2} \mathrm{O}$

3) $\mathrm{Li}_{2} \mathrm{C}_{2}+\mathrm{H}_{2} \mathrm{O}_{2} \rightarrow \mathrm{C}_{2} \mathrm{H}_{2}+2 \mathrm{Li} \mathrm{OH}$

4) $3 \mathrm{C}_{2} \mathrm{H}_{2}$ catalysis $\mathrm{C}_{6} \mathrm{H}_{6}$

These chemical procedures are essentially the same as have been used by this laboratory since it began operations in the fall of 1963. During the past year, however, a considerable amount of time was devoted to research work on a new catalyst to be used for the condensation of acetylene to benzene. This is the most inefficient procedure in the entire chemical conversion.

The catalyst which had been used previously was a cracking catalyst which had to be activated with the highly flammable and toxic gas, diborane. Although the catalyst was commercially available from Packard Instrument Company in its activated form, it was expensive and difficult to handle since contact with oxygen would cause deactivation. The chemical yields for the synthesis were in the range of $35-55 \%$.

During the past year, it was discovered that the Isotope Center in Copenhagen, Denmark had used a different catalyst for benzene synthesis. The work in Denmark, however, was preliminary and had been abandoned after a short time. It was continued in our laboratory and a new procedure was developed which proved to be far superior to the previous one.

This new acetylene to benzene conversion catalyst which is now commercially available (Packard Instrument Co. catalog No. 6008077 for $600 \mathrm{gms}$ or No. 6008078 for $1200 \mathrm{gms}$ ) is also a cracking catalyst and produces the reaction in much the same way as the old catalyst. The catalyst beads are poured into a glass catalyst column. The entire 
column is heated by a heating jacket to $300^{\circ} \mathrm{C}$ for $11 / 2$ hrs. During this period a vacuum is applied to the column through a glass trap which is cooled with a dry ice-isopropyl alcohol slurry. This allows moisture from the catalyst to be frozen into the cold trap. When all moisture has been removed, the entire column is allowed to cool to room temperature while racuum conditions are maintained. This column is then heated to slightly above room temperature and the acetylene, which had been frozen into a cold trap, is allowed to sublime onto the evacuated column. When all the acetylene has been taken up by the catalyst, the column is heated to $150^{\circ} \mathrm{C}$ while a vacuum is again applied, the trap now being cooled with liquid nitrogen. This allows pure benzene to be frozen into the trap.

We have found this new method to be superior, in that (1) conversion efficiencies have increased from $35-50 \%$ to $60-80 \%$, (2) the cost of the catalyst is reduced by one-half, and (3) no precautions need be taken to protect the catalyst from atmospheric oxygen.

The dates reported here have been calculated using the Libby halflife value for $\mathrm{C}^{14}$ of $5570 \pm 30 \mathrm{yr}$ with 1950 as the standard year of reference.

\section{ACKNOWLEDGMENTS}

Samples were contributed and dates evaluated by Robert C. Becker of the Artic Aeromedical Laboratory, U. S. Air Force, Ft. Wainwright, Alaska: William H. Taft of the University of South Florida, Tampa, Florida; W. J. Wayne, Dept. of Geology, Indiana University, Bloomington, Indiana; and I. L. Barnes of the University of Hawaii.

Mr. Tony Mrkvicka assisted in the chemical preparation of the samples and Miss Mary Hollenback assisted with manuscript preparation.

\section{SAMPLE DESCRIPTIONS}

\section{GEOLOGIC: SAMPLES}

\section{Ready Bullion Creek series}

Samples from exposure of Pleistocene muck $10 \mathrm{mi} \mathrm{W}$ of Fairbanks, Alaska, in Ready Bullion Creek Valley $\left(64^{\circ} 51^{\prime} \mathrm{N}\right.$ Lat, $148^{\circ} 01^{\prime} \mathrm{W}$ Long). Permafrost at this location is being continuously thawed and washed down the creek, exposing bedrock below. There is definite line of demarcation (color change) between bottom of Wisconsin silt and top of Illinoian layer. Wisconsin layer is approx. $34 \mathrm{ft}$ thick at this exposure.

The first group of samples from this series was reported in the previous publication from this lab.

All samples coll. 1964 by T. L. Péwé and R. C. Becker; subm. by R. C. Becker, Artic Aeromedical Lab., Ft. Wainwright, Alaska. 


\section{PIC-11. Ready Bullion Creek 6}

Wood from $2 \mathrm{ft}$ below surface, 6 in. above base of engineer muck (perennially frozen). Comment: dates early part of engineer muck and was estimated at 3000-5000 yr. Since date obtained in lab. was considerably older than estimate, sample was analyzed a second time and a date of $7665 \pm 220 \mathrm{yr}$ was obtained. This agreed closely with the first lab. date $(7530 \pm 265 \mathrm{yr})$. In addition, a sample (PIC-5) reported in our previous publication was taken 6 to 12 in. below this sample in 1963 from a nearby location and gave age of $8080 \pm 165 \mathrm{yr}$ so that the field estimate is probably in error.

\section{PIC-12. Ready Bullion Creek 7}

$\mathbf{2 7 , 5 8 0} \pm \mathbf{9 5 0}$

Wood fragments from $29 \mathrm{ft}$ below surface, $4 \mathrm{ft}$ below base of muck layer. Comment: sample dates top of "barren" loess layer. There was no estimate of sample age but since this sample was taken from a point farther below surface than previous samples in this series, it is not inconceivable that it would give the oldest date. However, a sample taken from below this point (PIC-13, this date list), though estimated to be $38,000 \mathrm{yr}$, was dated as $18,252 \pm 1130 \mathrm{yr}$.

\section{PIC-13. Ready Bullion Creek 8}

$18,250 \pm 1130$

Twigs from $38 \mathrm{ft}$ below surface. Dates loess layer which is perennially frozen. Comment: estimated at more than 38,000 yr. Laboratory analysis showed this sample to be more recent than both the estimated date and samples PIC-12 and PIC-14 which were located closer to the surface.

\section{PIC-14. Ready Bullion Creek 9}

$35,475 \pm 3250$

Wood pieces taken from slightly higher than $29 \mathrm{ft}$ below surface. Comment: sample collected in 1965 from same approx. point as PIC-12. Purpose of sample was to be certain that PIC-12 and PIC-13 were not reversed. This "rough" date showed that samples were not mixed, but does not decide whether PIC-13 was contaminated or if there was a shift in the earth's layers.

\section{PIC-15. Yellow Bank, Bahamas 1}

Partially cemented limestone taken from 2 in. below sediment/water interface near Yellow Bank, Bahamas ( $24^{\circ} 55^{\prime} \mathrm{N}$ Lat, $77^{\circ} 2^{\prime} \mathrm{W}$ Long). Water depth 17 ft. Coll. 1964 by W. H. Taft; subm. 1965 by William H. Taft, Univ. of South Florida, Tampa, Florida. Sample dates rise of sealevel and age of cementation. Comment: date is only slightly older than estimated age of $1800 \mathrm{yr}$. 


\section{PIC-16. Yellow Bank, Bahamas 2}

Partially cemented limestone taken from 36 in. below sediment/ water interface near Yellow Bank, Bahamas $\left(24^{\circ} 55^{\prime} \mathrm{N}\right.$ Lat, $77^{\circ} 2^{\prime} \mathrm{W}$ Long). Water depth is $17 \mathrm{ft}$. Coll. 1964 by W. H. Taft; subm. 1965 by William H. Taft. Sample dates rise of sealevel, age of cementation, and rate of sedimentation. Comment: date is slightly older than estimated age of $4000 \mathrm{yr}$.

\section{PIC-17. Hendricks County, Indiana}

$19,930 \pm 990$

Wood from road cut along Indiana 136 in northwestern Hendricks County, Indiana, from fossiliferous silt bed between Cartersburg and Center Grove tills. Coll. and subm. by W. J. Wayne, Dept. of Geology, Indiana Univ., Bloomington, Indiana. Comment: confirms estimated age of $19,000-20,000 \mathrm{yr}$.

\section{PIC-18. Montgomery County, Indiana}

Wood from alluvial sands and silts below Wisconsin till in stream cut in Montgomery County, Indiana. Coll. and subm. by W. J. Wayne. Comment: confirms estimated age of 20,000-24,000 yr.

\section{ARCHAEOLOGIC SAMPLES}

PIC-19. Hane Dune Site

Modern $<\mathbf{1 8 7}$

Charcoal from a fisherman's habitation site on top of dune at Hane, Uahuka Island, Marquesas, French Polynesia. Site is located on back of beach a. $60 \mathrm{~m}$ from shore and $10 \mathrm{~m}$ above sealevel $\left(8^{\circ} 55^{\prime} 36^{\prime \prime} \mathrm{S}\right.$ Lat, $139^{\circ} 32^{\prime} 3^{\prime \prime} \mathrm{W}$ Long). There were three floor pavements in succession. Two were near the top and the third, in which eight human burials were found, was below $1 \mathrm{~m}$ sand. Sample taken from fireplace on Level III below second paved floor, thought to indicate beginning of Marquesas Classic Period. Coll. 1964 by Y. Sinoto and M. Kellum, Bernice P. Bishop Mus., Honolulu, Hawaii; subm. 1964 by I. L. Barnes, Univ. of Hawaii, Honolulu, Hawaii. Comment: tidal waves hit the site area which could cause contamination. A portion of the same sample was dated by Dr. Kunihiko Kigoshi, Gakushuin Univ., Tokyo, Japan as Gak-538, Modem $<180$ (Gakushuin V). This agreement with the Packard date indicates the sample, estimated at $450 \mathrm{yr}$, was contaminated.

Date lists:

REFERENCES

Gakushuin V Kigoshi and Kobayashi, 1966

Packard I Kowalski, 1965

Kigoshi, Kunihiko, and Kobayashi, Hiromi, 1966, Gakushuin natural radiocarbon measurements V: Radiocarbon, v. 8, p. 54-73.

Kowalski, S. J.. 1965, Packard Instrument Company radiocarbon dates I: Radiocarbon, v. 7 , p. $200-204$. 